\title{
Serum visfatin levels in acromegaly: Correlation with disease activity and metabolic alterations论论坛 $\star$
}

\author{
A. Ciresi, M.C. Amato, G. Pizzolanti, C. Giordano* \\ Biomedical Department of Internal and Specialist Medicine (DIBIMIS), Section of Endocrinology, University of Palermo, Italy
}

\section{A R T I C L E I N F O}

\section{Article history:}

Received 17 May 2015

Received in revised form 30 June 2015

Accepted 5 July 2015

Available online 11 July 2015

\section{Keywords:}

Acromegaly

Growth hormone

Adipokines

\begin{abstract}
A B S T R A C T
Objective: The studies that have extensively evaluated the relation between adipokines and metabolic parameters in acromegaly treatment are quite discordant. We aimed to evaluate and correlate a set of selected adipokines, known to have a metabolic role, with the disease activity, metabolic status and treatment modalities.

Design: Data of 56 consecutive acromegalic patients ( $31 \mathrm{M}$ and $25 \mathrm{~F}$; aged $54 \pm 12$ years), admitted to the section of Endocrinology of the University of Palermo during the years 2005-2014, including 16 newly diagnosed untreated $(N D), 21$ during therapy with somatostatin analogues $(S A), 12$ with pegvisomant $(P E)$ and 7 after surgical treatment (SU), grouped into uncontrolled (group A: No. 33) and controlled (group B: No. 23) were evaluated. Anthropometric and metabolic parameters, insulin sensitivity indexes, visceral adiposity index (VAI), leptin, soluble leptin receptor, adiponectin, visfatin, resistin, adipsin and non-esterified fatty acids (NEFAs) were assessed. In a subgroup of 21 subjects, the insulin sensitivity index ( $M$ value) derived from euglycemic clamp was calculated.

Results: Group A showed higher Homa-IR ( $\mathrm{p}<0.001)$, VAI $(\mathrm{p}<0.001)$, triglycerides $(\mathrm{p}<0.001)$, visfatin $(\mathrm{p}<0.001)$, and NEFAs ( $<<0.001)$ and lower ISI Matsuda ( $<<0.001)$, M value $(\mathrm{p}<0.001)$, HDL cholesterol $(\mathrm{p}<0.001)$ and leptin $(\mathrm{p}<0.001)$ than group B. ND patients showed higher VAI, triglycerides, Homa-IR, and visfatin and lower ISI Matsuda, M-value, and leptin compared to other groups (all $\mathrm{p}<0.050$ ), while no differences were found among $S A, P E$ and $S U$ patients. IGF-1 $(p=0.048)$, M-value $(p=0.0029)$ and VAI $(p=0.010)$ were independently associated with visfatin, while only ISI Matsuda $(\mathrm{p}=0.019)$ was associated with leptin.

Conclusions: In acromegaly visfatin could be considered a useful index of disease activity and metabolic alterations, such as insulin resistance and adipose dysfunction, regardless of the type of treatment.
\end{abstract}

(c) 2015 Elsevier Ltd. All rights reserved.

\section{Introduction}

The growth hormone (GH) has metabolic effects on peripheral tissues in addition to the growth promoting role, including the stimulation of gluconeogenesis and lipolysis, which results in increased glucose and free fatty acid (FFA) levels and the adipose tissue is one of the key target organs of $\mathrm{GH}$ action [1-3].

In acromegaly, the $\mathrm{GH}$ excess leads to an alteration in adipose tissue distribution and function through a lipolytic effect and an increased FFA flux from adipose to peripheral tissues and this condition appears to be directly associated with disease activity and insulin resistance [4,5]. The

Abbreviations: ND, newly diagnosed; SA, somatostatin analogues; PE, pegvisomant; SU, surgical treatment; VAI, visceral adiposity index; NEFAs, non-esterified fatty acids.

th Grants: This research did not receive any specific grant from any funding agency in the public, commercial or non-profit sector.

话访 Disclosure statement: The authors have nothing to disclose.

$\star$ Conflict of interest: The authors declare that they have no conflict of interest.

* Corresponding author at: Section of Endocrinology, Dipartimento Biomedico di Medicina Interna e Specialistica (Di.Bi.Mi.S), University of Palermo, Piazza delle Cliniche 2, 90127 Palermo, Italy.

E-mail address: carla.giordano@unipa.it (C. Giordano). white visceral adipose tissue produces different mediators, the adipokines, and a strong association between metabolic risk and fat distribution or adipokine levels has recently been documented [6]. The adipose dysfunction, resulting in higher lipolytic activity, changes the production and secretion of adipokines known to play a role in the pathogenesis of low-grade systemic inflammation and insulin resistance [7], leading to a cardiovascular disease and systemic metabolic complications [8,9]. In this view, the relation between GH and adipokine levels could explain the metabolic risk associated with acromegaly, although to date the data on adipokine levels in acromegaly are discordant.

The primary outcome of this study was to evaluate a set of selected adipokines, known to have a metabolic role $[10,11]$, in patients with acromegaly and to correlate them with the disease activity and the metabolic status. In addition, we aimed to investigate the effect of different treatment modalities on adipokine levels.

\section{Materials and methods}

This is a cross-sectional study. For the purpose of the study we analyzed the data of fifty-six outpatients ( 31 males and 25 females; aged $54 \pm 12$ years, range 25-79) with acromegaly, admitted to the 
section of Endocrinology of the University of Palermo during the years 2005-2014.

A subset of patients was already included in our previous study aimed to investigate leptin and adiponectin levels in newly diagnosed acromegalic patients [4]. In the current study we have performed a more detailed analysis, by including other adipokines, in a larger group of patients and during different treatment modalities, to avoid reporting data already published. Therefore, in this paper the case load includes only 16 of 24 patients previously published and the other cases are entirely unpublished. The duration of disease was established by patient interview, patients' clinical pictures and onset of osteoarticular symptoms. Patients with mixed GH/PRL-secreting adenoma and with deficiency of one or more anterior pituitary hormones were excluded from this study to avoid the potential impact of hormonal deficit or replacement therapy on $\mathrm{GH}$, insulin growth factor-1 (IGF-1), as well as metabolic parameters.

Sixteen patients were newly diagnosed $(N D)$, while the remaining were treated with somatostatin analogues ( $S A, 21$ patients) and pegvisomant ( $P E, 12$ patients) or had undergone surgery 6 months previously (SU, 7 patients). Specifically, among patients treated with SA, 14 (67\%) received octreotide long-acting release (LAR) (10-40 mg every 28 days) and 7 (33\%) lanreotide autogel (ATG) (60-120 mg every 28 days). In the octreotide-group, 6 patients were treated with a monthly dose of $20 \mathrm{mg}, 5$ with $30 \mathrm{mg}$, 2 with $10 \mathrm{mg}$ and 1 with $40 \mathrm{mg}$; in the lanreotide-group, 4 patients were treated with a monthly dose of $120 \mathrm{mg}, 2$ with $90 \mathrm{mg}$ and 1 with $60 \mathrm{mg}$ of ATG. The activity of disease at the time of the study was confirmed by plasma mean $\mathrm{GH}$ profile, elevated age- and gender-corrected plasma IGF-1 levels and nonsuppressible GH after OGTT [12]. According to these criteria, all patients were grouped into those with uncontrolled (group A: 33 patients, including $16 \mathrm{ND}, 10 \mathrm{SA}, 5 \mathrm{PE}, 2 \mathrm{SU}$ ) and controlled (group B: 23 patients, including $11 S A, 7 P E, 5 S U$ ) disease. Each group of patients was matched by gender, BMI and WC, to avoid the interference of these variables on metabolic evaluation.

At the time of hospitalization, all patients signed a consent form for the scientific use of their data after a full explanation of the purpose of the study. This study was approved by the Institutional Review Board of the Faculty of Medicine, University of Palermo and the identity of the participants remained anonymous during database analysis.

\section{Study design}

Body mass index (BMI) and systolic (SBP) and diastolic (DBP) blood pressure were measured in all patients. WC was measured at the midpoint between the lower rib and the iliac crest. After an overnight fast, lipid profile (total, HDL- and LDL-cholesterol, triglycerides), hemoglobinA1c (HbA1c), mean fasting plasma GH (at least three blood samples at 30-min intervals) and IGF-1 levels were measured. To normalize IGF-1 in individual patients, we calculated the ratio between the IGF-1 level and the upper limit of the normal (ULN) range for age and gender (normal $=\leq 1$ ) and the data are presented as IGF-1 ULN. GH levels were not evaluated in patients treated with PE. OGTT was performed in all patients by measuring plasma blood glucose, insulin levels and GH every $30 \mathrm{~min}$ for $2 \mathrm{~h}$ after $75 \mathrm{~g}$ oral glucose load. Basal insulin resistance was assessed using homeostasis model assessment of the insulin resistance (Homa-IR) index [13]. Stimulated insulin sensitivity was measured using the insulin sensitivity index (ISI), a composite index derived from the OGTT and validated by Matsuda and De Fronzo [14].

In a subgroup of 21 subjects ( 11 uncontrolled and 10 controlled, including 7 patients $N D, 6 S A, 4 P E$ and $4 S U$ ) on a different day (day-2) a euglycemic hyperinsulinemic clamp was used to determine the insulin-sensitivity. One catheter was placed in a vein on the forearm for administration of insulin and glucose and the second catheter was placed in a vein of the contralateral forearm for blood samples. The clamp was performed under standard conditions, i.e. the plasma insulin concentration was acutely raised with an insulin priming (0-3 min: $113.6 \mathrm{mU} / \mathrm{m}^{2}, 3-6 \mathrm{~min}: 80.2 \mathrm{mU} / \mathrm{m}^{2}, 7-10 \mathrm{~min}: 50.4 \mathrm{mU} / \mathrm{m}^{2}$ of body surface area) for the first 10 min of the test and maintained by a continuous infusion of insulin infusion ( $40 \mathrm{mU} / \mathrm{m}^{2}$ for the remaining $110 \mathrm{~min}$ ). The rate of peripheral glucose utilization (M value) was calculated by dividing the glucose amount infused during the last 40 min by body weight measured in kilograms (milligrams per kilogram per minute). The plasma glucose concentration was held constant at basal levels by a variable glucose infusion and under the steady-state conditions of euglycemia the glucose infusion rate equalled glucose uptake by all the tissues in the body and it was therefore considered a measure of tissue sensitivity to exogenous insulin [15].

To evaluate the adipose function, in all patients we measured the visceral adiposity index (VAI), differentiated according to sex and calculated as described [16], and the serum levels of leptin, soluble leptin receptor (sOB-R), adiponectin, visfatin, resistin, adipsin and nonesterified fatty acids (NEFAs) after an overnight fast.

All patients affected by impaired fasting glucose (IFG) or impaired glucose tolerance (IGT) were treated with diet alone. Patients with overt diabetes mellitus and those receiving hypoglycemic agents were excluded from this study to avoid the effect of glucotoxicity or of drugs on the adipokine levels and insulin-sensitivity indexes.

\subsection{Hormone and biochemical assays}

All biochemical data were collected after overnight fasting. Glycemia, HbA1c and lipid levels were measured in our centralized accredited laboratory with standard methods. Serum insulin was measured by ELISA (DRG Instruments GmbH, Germany). The sensitivity of the method was $1 \mathrm{IU} / \mathrm{ml}$. The normal insulin range (IU/ml) was 5-19. GH levels were assayed by immunoradiometric assay (Radim, Pomezia, Italy). The sensitivity of the assays was $0.05 \mu \mathrm{g} / \mathrm{l}$. The intra- and inter-assay coefficients of variation (CV) were 4.5 and $7.9 \%$, respectively. Serum IGF-1 was measured using immunoradiometric assays (Diagnostic System Laboratories Inc., Webster, TX). The normal ranges (for age) were: $118-475$ and $118-450$ (21-30), 102-400 and 100-390 (31-40), $100-306$ and 96-228 (41-50), 95-270 and 90-250 (51-60), 88-250 and $82-200$ (61-70), 78-200 and 68-188 $\mu \mathrm{g} / \mathrm{l}(\geq 70)$ for men and women, respectively. The sensitivity of the assay was $0.8 \mu \mathrm{g} / \mathrm{l}$. The intra- and inter-assay CVs were 3.4, 3.0 and $1.5 \%$, and 8.2, 1.5 and 3.7\% for low, medium and high points on the standard curve, respectively.

The BioPlex Pro Human Diabetes 10-plex assay (BioRad, Milan, Italy) was used to quantitate leptin $(\mathrm{ng} / \mathrm{ml})$, resistin $(\mathrm{ng} / \mathrm{ml})$ and visfatin $(\mathrm{pg} / \mathrm{ml})$. The BioPlex Pro Human Diabetes Adipsin and Adiponectin duplex assay (BioRad, Milan, Italy) was used for adipsin $(\mathrm{ng} / \mathrm{ml})$ and adiponectin $(\mu \mathrm{g} / \mathrm{ml})$. Human sOB-R $(\mathrm{ng} / \mathrm{ml})$ was assayed using an ELISA sandwich enzyme immunoassay (Human leptin receptor ELISA, BioVendor, Heidelberg, Germany). NEFAs ( $\mathrm{mmol} / \mathrm{l}$ ) were assayed using an enzymatic colorimetric method (Randox NEFA assay FA115, Randox Laboratories, County Antrim, UK).

\subsubsection{Statistical analysis}

The Statistical Packages for Social Sciences SPSS version 17 was used for data analysis. Baseline characteristics were presented as mean \pm Standard Deviation (SD); rates and proportions were calculated for categorical data. The normality of distribution of the quantitative variables was assessed by means of the Kolmogorov-Smirnov test. The differences between the two groups of patients (with controlled or uncontrolled disease) were evaluated with the Student's t-test. Continuous variables were analyzed with a one-way ANOVA and the differences between the groups of patients with different type of treatment were evaluated by ANOVA for repeated measures with a Bonferroni test for the post hoc analysis. Simple univariate correlations among continuous variables with normal distribution were determined by Pearson's test. To evaluate the independent variables influencing leptin and visfatin in all acromegalic patients a linear regression model was performed. A p value of $<0.05$ was considered statistically significant. 


\section{Results}

\subsection{Characteristics of patients grouped according to disease control}

The clinical and biochemical features of patients according to disease control are shown in Table 1.

Group A showed higher DBP $(82.9 \pm 12.6$ vs. $75.2 \pm 9.5 \mathrm{~mm} \mathrm{Hg} ; \mathrm{p}=$ $0.034)$, fasting insulin ( $14.4 \pm 12.7$ vs. $6.2 \pm 4.1 \mathrm{IU} / \mathrm{ml} ; \mathrm{p}=0.034)$, Homa-IR ( $4 \pm 2.1$ vs. $1.3 \pm 0.5 ; \mathrm{p}<0.001)$, VAI $(3.4 \pm 1$ vs. $1.3 \pm 0.6$; $\mathrm{p}<0.001)$, triglycerides $(160.5 \pm 33.3$ vs. $93.3 \pm 24.6 \mathrm{mg} / \mathrm{dl} ; \mathrm{p}<$ $0.001)$ and lower ISI Matsuda ( $1.9 \pm 0.4$ vs. $4.84 \pm 1.44 ; \mathrm{p}<0.001)$, HDL cholesterol $(43.2 \pm 7.45$ vs. $53.5 \pm 10.1 \mathrm{mg} / \mathrm{dl} ; \mathrm{p}<0.001)$ than group $B$, while no significant difference in duration of disease, WC, BMI, SBP, fasting glucose, Hba1c, total and LDL-cholesterol was found (Table 1).

In the subgroup of 21 patients, the $M$ value derived from clamp showed significant lower values in group $A$ than group $B(1.3 \pm 0.6$ vs. $2.9 \pm 0.8 \mathrm{mg} / \mathrm{dl} ; \mathrm{p}<0.001$ ).

In addition, group $A$ showed significantly higher levels of visfatin $(1.51 \pm 0.44$ vs. $0.21 \pm 0.22 \mathrm{pg} / \mathrm{ml} ; \mathrm{p}<0.001)$ and NEFAs $(0.54 \pm$ 0.06 vs. $0.36 \pm 0.01 \mathrm{mmol} / \mathrm{l} ; \mathrm{p}<0.001$ ), higher although not significantly levels of resistin ( $1.72 \pm 0.62 \mathrm{vs} .1 .40 \pm 0.58 \mathrm{ng} / \mathrm{ml} ; \mathrm{p}=0.056)$ and significantly lower levels of leptin $(0.89 \pm 0.55$ vs $3.49 \pm 1.28 \mathrm{ng} / \mathrm{ml} ; \mathrm{p}<$ 0.001 ), while no significant difference in adiponectin (5.43 $\pm 4.81 \mathrm{vs.}$ $5.38 \pm 3.71 \mu \mathrm{g} / \mathrm{ml} ; \mathrm{p}=0.965)$, adipsin $(0.26 \pm 0.14$ vs. $0.30 \pm$ $0.13 \mathrm{ng} / \mathrm{ml} ; \mathrm{p}=0.401)$ and sOB-R (19.55 \pm 8.57 vs. $18.59 \pm$ $4.45 \mathrm{ng} / \mathrm{ml} ; \mathrm{p}=0.965$ ) was found (Table 1 ).

\subsection{Characteristics of patients grouped according to acromegaly treatment}

The clinical and biochemical features of patients according to acromegaly treatment are shown in Table 2 .

ND patients showed higher VAI, triglycerides, Homa-IR and lower ISI Matsuda, M-value compared to any other group of patients and higher fasting insulin than $P E$, while no difference in metabolic parameters was found among $S A, P E$ and $S U$ patients (Table 2).

When we compared the adipokine levels according to treatment for acromegaly, we found lower levels of leptin in $N D$ patients $(0.86 \pm$ $0.66 \mathrm{ng} / \mathrm{ml})$ than in patients treated with $S A(2.08 \pm 1.67 \mathrm{ng} / \mathrm{ml} ; \mathrm{p}=$ $0.030), P E(2.91 \pm 1.28 \mathrm{ng} / \mathrm{ml} ; \mathrm{p}=0.027)$ or $S U(3.33 \pm 1.62 \mathrm{ng} / \mathrm{ml}$; $\mathrm{p}=0.031)$ in concomitant with higher visfatin levels $(1.54 \pm 0.58 \mathrm{pg} /$ $\mathrm{ml})$ than $S A(0.86 \pm 0.62 \mathrm{pg} / \mathrm{ml} ; \mathrm{p}=0.012), P E(0.32 \pm 0.51 \mathrm{pg} / \mathrm{ml}$; $\mathrm{p}=0.034)$ and $S U$ patients $(0.48 \pm 0.65 \mathrm{pg} / \mathrm{ml} ; \mathrm{p}=0.022)$, while no difference in adiponectin, adipsin, resistin, sOB-R and NEFAs was found (Fig. 1, Table 2).

In univariate analysis, leptin was found to be correlated with $\mathrm{GH}$ nadir $(\mathrm{r}-0.430 ; \mathrm{p}=0.009)$, IGF-1 $(\mathrm{r}-0.594 ; \mathrm{p}<0.001)$, Homa-IR $(\mathrm{r}-0.446$; $\mathrm{p}=0.001$ ), ISI Matsuda ( $\mathrm{r} 0.663 ; \mathrm{p}<0.001)$ and VAI $(\mathrm{r}-0.500 ; \mathrm{p}<$ 0.001 ), visfatin was found to be correlated with IGF-1 ( $\mathrm{r} 0.683 ; \mathrm{p}<$ 0.001), Homa-IR ( $\mathrm{r}$ 0.558; $\mathrm{p}<0.001$ ), ISI Matsuda ( $\mathrm{r}-0.701$; $\mathrm{p}<$ 0.001), M-value ( $\mathrm{r}-0.447 ; \mathrm{p}=0.042$ ) and VAI ( $\mathrm{r} 0.724 ; \mathrm{p}<0.001$ ), while no correlation was found with WC and BMI. IGF-1, as expected, correlates with GH nadir ( $\mathrm{r} 0.620 ; \mathrm{p}<0.001$ ) and also with Homa-IR ( $\mathrm{r} 0.622 ; \mathrm{p}<0.001$ ), ISI Matsuda ( $\mathrm{r}-0.575 ; \mathrm{p}<0.001$ ), M-value ( $\mathrm{r} 0.616 ; \mathrm{p}=0.003$ ) and VAI (r 0.595; $\mathrm{p}<0.001$ ) (Table 3$)$.

Table 1

Clinical and biochemical features of patients grouped according to disease control.

\begin{tabular}{|c|c|c|c|}
\hline & $\begin{array}{l}\text { Acromegalic patients with uncontrolled disease (group A) No. } 33 \\
(59 \%)\end{array}$ & $\begin{array}{l}\text { Acromegalic patients with controlled disease (group B) No. } 23 \\
(41 \%)\end{array}$ & \\
\hline & Subjects (\%) & Subjects (\%) & $\mathrm{p}$ \\
\hline Gender & & & 0.689 \\
\hline Males & $19(57.6)$ & $12(52.2)$ & \\
\hline \multirow[t]{2}{*}{ Females } & $14(42.4)$ & $11(47.8)$ & \\
\hline & Mean \pm SD & Mean \pm SD & \\
\hline Age (years) & $53.3 \pm 10.5$ & $56.1 \pm 14.2$ & 0.354 \\
\hline BMI $\left(\mathrm{kg} / \mathrm{m}^{2}\right)$ & $29.4 \pm 2.9$ & $29.2 \pm 3$ & 0.795 \\
\hline Waist circumference (cm) & $96.1 \pm 11$ & $99.2 \pm 8.5$ & 0.267 \\
\hline Visceral adiposity index & $3.4 \pm 1$ & $1.3 \pm 0.6$ & $<0.001$ \\
\hline Duration of disease (years) & $7.5 \pm 4.6$ & $7.7 \pm 4.7$ & 0.926 \\
\hline Systolic blood pressure (mm Hg) & $135.3 \pm 24$ & $126.1 \pm 14.2$ & 0.159 \\
\hline Diastolic blood pressure (mm Hg) & $82.9 \pm 12.6$ & $75.2 \pm 9.5$ & 0.034 \\
\hline GH nadir after OGTT $(\mu \mathrm{g} / \mathrm{l})$ & $11.8 \pm 13.7$ & $0.8 \pm 0.6$ & $<0.001$ \\
\hline IGF1 (ULN) & $2 \pm 0.9$ & $0.5 \pm 0.2$ & $<0.001$ \\
\hline Fasting glucose (mmol/l) & $5.9 \pm 0.8$ & $5.7 \pm 0.7$ & 0.469 \\
\hline Fasting insulin (IU/ml) & $14.4 \pm 12.7$ & $6.2 \pm 4.1$ & 0.034 \\
\hline $\operatorname{HbA1c}(\%)$ & $6.4 \pm 1.3$ & $6.1 \pm 1.2$ & 0.363 \\
\hline Total cholesterol (mg/dl) & $186.4 \pm 40.8$ & $189.8 \pm 45.5$ & 0.794 \\
\hline HDL cholesterol (mg/dl) & $43.2 \pm 7.4$ & $53.5 \pm 10.1$ & $<0.001$ \\
\hline LDL cholesterol (mg/dl) & $108.9 \pm 42.7$ & $133.2 \pm 48.4$ & 0.313 \\
\hline Triglycerides (mg/dl) & $160.5 \pm 33.3$ & $93.3 \pm 24.6$ & $<0.001$ \\
\hline Homa IR & $4 \pm 2.1$ & $1.3 \pm 0.5$ & $<0.001$ \\
\hline ISI Matsuda & $1.9 \pm 0.4$ & $4.8 \pm 1.4$ & $<0.001$ \\
\hline M value (clamp) ${ }^{\mathrm{a}}$ & $1.7 \pm 0.7$ & $2.9 \pm 0.8$ & 0.001 \\
\hline Leptin $(\mathrm{ng} / \mathrm{ml})$ & $0.89 \pm 0.55$ & $3.49 \pm 1.28$ & $<0.001$ \\
\hline Adiponectin $(\mu \mathrm{g} / \mathrm{ml})$ & $5.43 \pm 4.81$ & $5.38 \pm 3.71$ & 0.965 \\
\hline Resistin (ng/ml) & $1.72 \pm 0.62$ & $1.40 \pm 0.58$ & 0.056 \\
\hline Visfatin (pg/ml) & $1.51 \pm 0.44$ & $0.21 \pm 0.22$ & $<0.001$ \\
\hline Adipsin (ng/ml) & $0.26 \pm 0.14$ & $0.30 \pm 0.13$ & 0.401 \\
\hline $\mathrm{sOB}-\mathrm{R}(\mathrm{ng} / \mathrm{ml})$ & $19.55 \pm 8.57$ & $18.59 \pm 4.45$ & 0.624 \\
\hline NEFA (mmol/l) & $0.54 \pm 0.06$ & $0.36 \pm 0.01$ & $<0.001$ \\
\hline
\end{tabular}

OGTT: oral glucose tolerance test.

ULN: upper limit of normal range.

sOB-R = soluble leptin receptor.

NEFAs $=$ non-esterified fatty acids.

a Clamp was performed in a subgroup of 21 patients, including 11 uncontrolled and 10 controlled patients. 
Metabolic parameters and adipokine levels in acromegalic patients grouped according to acromegaly treatment.

\begin{tabular}{|c|c|c|c|c|c|c|c|c|c|c|}
\hline & $\begin{array}{l}\text { Newly diagnosed } \\
\text { patients }(N D) \\
\text { No. } 16(28.6 \%) \\
(\mathrm{M} / \mathrm{F}: 9 / 7)\end{array}$ & $\begin{array}{l}\text { Somatostatin } \\
\text { analogue-treated } \\
\text { patients }(S A) \\
\text { No. } 21(37.5 \%) \\
(\mathrm{M} / \mathrm{F}: 11 / 10)\end{array}$ & $\begin{array}{l}\text { Pegvisomant-treated } \\
\text { patients }(P E) \\
\text { No. } 12(21.4 \%)(\mathrm{M} / \mathrm{F}: 7 / 5)\end{array}$ & $\begin{array}{l}\text { Surgery-treated } \\
\text { patients }(\mathrm{SU}) \\
\text { No. } 7(12.5 \%) \\
(\mathrm{M} / \mathrm{F}: 4 / 3)\end{array}$ & & & & & & \\
\hline & Mean $\pm S D$ & Mean $\pm S D$ & Mean \pm SD & Mean $\pm S D$ & $\mathrm{p}$ & $\mathrm{p}^{1}$ & $\mathrm{p}^{2}$ & $\mathrm{p}^{3}$ & $\mathrm{p}^{4}$ & $\mathrm{p}^{5}$ \\
\hline BMI $\left(\mathrm{kg} / \mathrm{m}^{2}\right)$ & $29.7 \pm 2.8$ & $29.9 \pm 2.9$ & $28.5 \pm 2.7$ & $27.2 \pm 3.3$ & 1 & 1 & 0.472 & 1 & 0.298 & 1 \\
\hline Waist circumference $(\mathrm{cm})$ & $93.6 \pm 10.1$ & $99.5 \pm 10.2$ & $100.8 \pm 8.5$ & $96 \pm 10.2$ & 0.521 & 0.415 & 1 & 1 & 1 & 1 \\
\hline Visceral adiposity index & $3.5 \pm 1.3$ & $2.3 \pm 1$ & $2.1 \pm 1.1$ & $1.6 \pm 1.4$ & 0.039 & 0.046 & 0.012 & 0.998 & 0.878 & 0.981 \\
\hline Fasting glucose (mg/dl) & $5.5 \pm 0.7$ & $5.9 \pm 0.7$ & $5.9 \pm 1$ & $6.1 \pm 0.5$ & 0.986 & 1 & 0.727 & 0.936 & 0.561 & 1 \\
\hline Fasting insulin (IU/ml) & $17.4 \pm 12.1$ & $8.2 \pm 9.2$ & $3.4 \pm 0.1$ & $8.0 \pm 3.9$ & 0.185 & 0.003 & 0.120 & 0.411 & 1 & 0.330 \\
\hline $\operatorname{HbA1c}(\%)$ & $6.3 \pm 1.8$ & $6.4 \pm 1.2$ & $6.4 \pm 0.9$ & $5.7 \pm 0.9$ & 1 & 1 & 0.481 & 1 & 0.225 & 0.175 \\
\hline Total cholesterol (mg/dl) & $198.5 \pm 38.2$ & $183.7 \pm 46.1$ & $179.8 \pm 52.1$ & $186 \pm 33.9$ & 0.338 & 0.362 & 0.474 & 1 & 1 & 1 \\
\hline HDL cholesterol (mg/dl) & $44.1 \pm 8.8$ & $48.3 \pm 11.6$ & $50.7 \pm 8.8$ & $51 \pm 8.9$ & 1 & 0.931 & 1 & 0.602 & 0.610 & 1 \\
\hline LDL cholesterol (mg/dl) & $127.4 \pm 38.4$ & $129.8 \pm 60.1$ & $88.6 \pm 45$ & $104 \pm 17.2$ & 1 & 0.217 & 0.465 & 0.348 & 0.602 & 1 \\
\hline Triglycerides (mg/dl) & $168.3 \pm 40.9$ & $124.4 \pm 38.3$ & $125.4 \pm 38.1$ & $90.5 \pm 28.6$ & 0.013 & 0.048 & $<0.001$ & 1 & 0.138 & 0.195 \\
\hline Homa IR & $4.6 \pm 1.6$ & $2.6 \pm 2.4$ & $1.8 \pm 1.5$ & $2.6 \pm 1.6$ & 0.031 & 0.001 & 0.028 & 0.853 & 1 & 0.937 \\
\hline ISI Matsuda & $2.1 \pm 0.5$ & $3.3 \pm 1.9$ & $3.4 \pm 1.8$ & $4.2 \pm 1.9$ & 0.019 & 0.019 & 0.001 & 0.987 & 0.301 & 0.349 \\
\hline M-value (clamp) ${ }^{a}$ & $1.3 \pm 0.7$ & $3.2 \pm 0.9$ & $2.3 \pm 0.1$ & $2.4 \pm 0.1$ & 0.013 & 0.047 & 0.037 & 0.207 & 0.277 & 0.860 \\
\hline Leptin (ng/ml) & $0.86 \pm 0.66$ & $2.08 \pm 1.67$ & $2.91 \pm 1.28$ & $3.33 \pm 1.62$ & 0.030 & 0.027 & 0.031 & 0.992 & 0.443 & 0.761 \\
\hline sOB-R (ng/ml) & $19 \pm 10.4$ & $18.93 \pm 5.27$ & $21 \pm 1.35$ & $16.7 \pm 4.1$ & 1 & 1 & 1 & 1 & 1 & 1 \\
\hline Adiponectin (ng/ml) & $6.76 \pm 6.37$ & $5.15 \pm 3.56$ & $5.01 \pm 1.28$ & $3.89 \pm 2.46$ & 1 & 0.504 & 0.856 & 1 & 1 & 1 \\
\hline Resistin (ng/ml) & $1.75 \pm 0.74$ & $1.63 \pm 0.51$ & $1.60 \pm 0.52$ & $1.47 \pm 0.73$ & 1 & 0.879 & 1 & 1 & 1 & 1 \\
\hline Visfatin (pg/ml) & $1.54 \pm 0.58$ & $0.86 \pm 0.62$ & $0.32 \pm 0.51$ & $0.48 \pm 0.65$ & 0.012 & 0.0034 & 0.022 & 0.992 & 0.696 & 0.978 \\
\hline Adipsin (ng/ml) & $0.28 \pm 0.19$ & $0.28 \pm 0.11$ & $0.41 \pm 0.15$ & $0.23 \pm 0.06$ & 1 & 0.196 & 1 & 0.125 & 1 & 0.055 \\
\hline NEFAs (mmol/l) & $0.53 \pm 0.07$ & $0.44 \pm 0.11$ & $0.47 \pm 0.09$ & $0.47 \pm 0.05$ & 0.538 & 0.240 & 1 & 1 & 1 & 1 \\
\hline
\end{tabular}

$\mathrm{p}=$ difference between ND and SA.

$\mathrm{p}^{1}=$ difference between ND and PE.

$\mathrm{p}^{2}=$ difference between ND and SU.

$\mathrm{p}^{3}=$ difference between SA and PE.

$\mathrm{p}^{4}=$ difference between SA and SU.

$\mathrm{p}^{5}=$ difference between PE and SU.

$\mathrm{M} / \mathrm{F}=$ males/females.

a Clamp was performed in a subgroup of 21 patients, including 7 ND, 6 SA, 4 PE and 4 SU.

In multivariate analysis, IGF-1 ( $B$ 0.474; $\mathrm{p}=0.048$ ), M-value ( $B$ 0.420; $\mathrm{p}=0.0029)$ and VAI $(B 0.309 ; \mathrm{p}=0.010)$ were the variables independently associated with visfatin, while only ISI Matsuda ( $B$ 0.398; $\mathrm{p}=0.019$ ) was independently associated with leptin. Conversely, no independent correlations were found between metabolic parameters and IGF-1, with the exception of Homa-IR ( $B$ 0.332; p = 0.049) (Table 4).

\section{Discussion}

In the literature data on adipokines, such as adiponectin or leptin, in acromegaly are numerous but quite contradictory, while the possible relationship between other adipokines, as visfatin, and GH/IGF I levels or metabolic parameters have been poorly investigated. In this study, visfatin was found to correlate to adipose dysfunction and metabolic impairment in active acromegaly.

Acromegaly is well known to be associated with insulin resistance and various degrees of carbohydrate intolerance [17,18], although the pathogenesis of these disturbances is not yet completely known. In this study, as expected, uncontrolled or untreated patients showed a worse metabolic profile, with lower insulin sensitivity, worse lipid profile and higher visceral adiposity index. We already previously demonstrated that active acromegaly is strongly associated with visceral adiposity dysfunction $[4,19]$ and that both $S A$ and $S U$ treatment are able to improve it, as demonstrated by the significant VAI decrease after 12 months of therapy [20]. The alteration in visceral adiposity, both in excess and in deficiency, has been shown to be a main determinant of insulin resistance in non-acromegalic patients [21,22] and this relationship is mediated by adipokine secretion that may modulate insulin sensitivity [23]. Acromegaly is characterized by alteration in adipose distribution [5] and the direct effect of GH on adipose tissue is well known [1]. Therefore, we hypothesized that the adipose dysfunction in acromegaly is closely related to insulin resistance and metabolic alterations. For these reasons, we have analyzed some selected adipokines known to have a clear metabolic role. Leptin has an endocrine function in body weight regulation and a mutual relationship between leptin and $\mathrm{GH}$ has been demonstrated [24]. In this study we found lower leptin levels in acromegalic patients with uncontrolled than controlled disease, as well as in newly diagnosed and not treated patients than treated patients, without difference in SOB$R$. These data are consistent with many previous studies which have demonstrated lower leptin levels in active acromegalic patients with an increase after surgical or medical treatment [25-27], although other authors showed overlapped leptin values in many active acromegalic patients and control subjects or no difference after medical treatment $[28,29]$. Interestingly, in our cohort of patients no difference was found in leptin levels between patients treated with $S A, P E$ or $S U$, suggesting the main role of the disease control regardless of the type of treatment. Whether the leptin levels are influenced by hormonal or metabolic parameters is unclear. A correlation with BMI has not been unequivocally demonstrated $[25,30]$, as well as the correlation with GH and IGF-1 levels or insulin levels $[25,31,32]$. In univariate analysis we found a correlation between leptin and hormonal parameters (both GH and IGF-1), insulin-sensitivity indexes (Homa-IR, ISI Matsuda, M-value) and adipose dysfunction (VAI), without correlation with WC and BMI. Nevertheless, these data have not been confirmed by a linear regression model, where only insulin sensitivity seems to be the independent factor influencing leptin, and these data are partially consistent with some of the above mentioned studies. For these reasons, we believe that the hormonal parameters are not major regulators of leptin and that leptin in acromegaly cannot be considered as a specific and sensitive index of severity of disease or adipose dysfunction. Conversely, we found a strong correlation between visfatin and several hormonal and metabolic parameters in our cohort of patients. Visfatin, prevalently secreted by visceral adipose tissue, is known to be related with the alteration in visceral adipose tissue associated with insulin resistance in non-acromegalic patients $[33,34]$. Although acromegaly is characterized by both adipose 

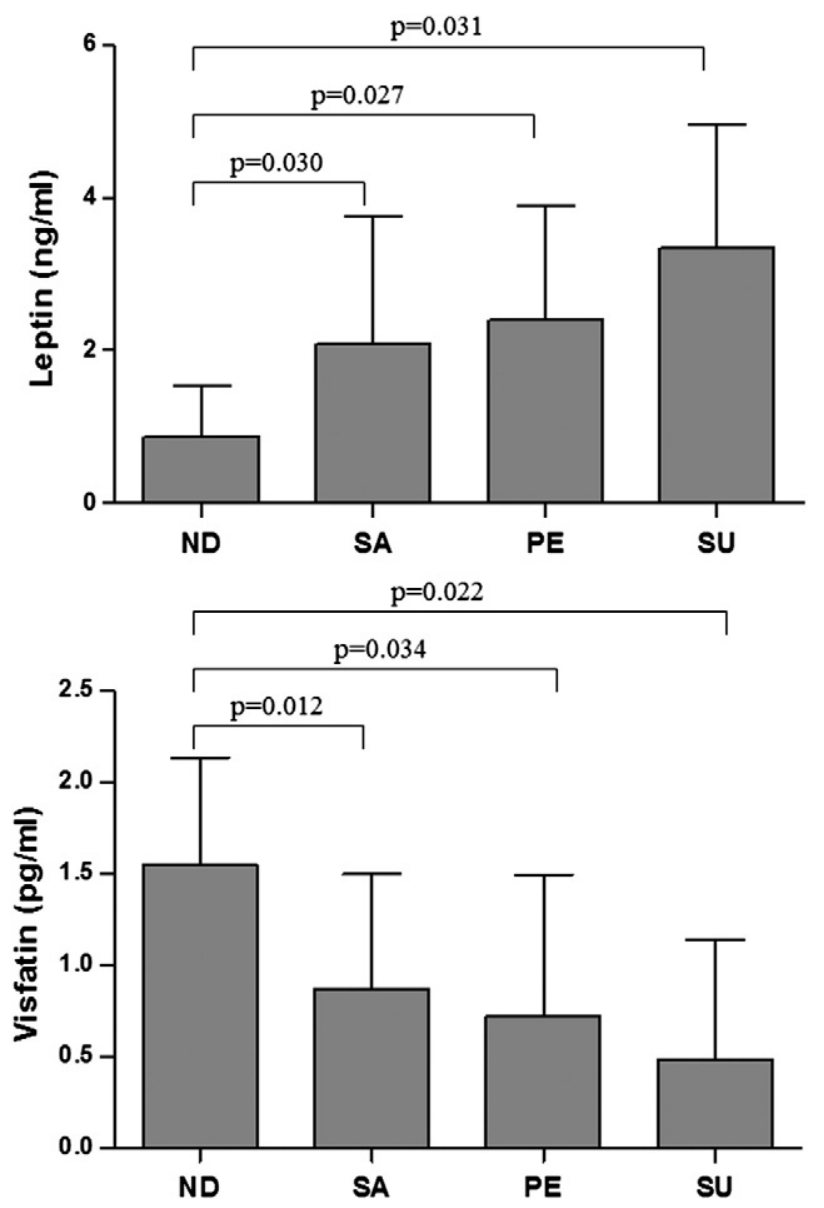

Fig. 1. Leptin (on the top) and visfatin (on the bottom) levels in acromegalic patients grouped according to treatment practiced. $N D$ : newly diagnosed without acromegaly treatment; $S A$ : in therapy with somatostatin analogues; $P E$ : in therapy with pegvisomant; $S U$ : after surgery.

dysfunction and insulin resistance, data on visfatin levels in acromegaly are very scarce and in the few existing studies no difference was reported in visfatin levels between acromegalic patients and controls [35].

In the current study, the patients with uncontrolled or untreated disease showed higher visfatin, which strongly correlates with IGF-1 levels, insulin sensitivity and visceral adiposity dysfunction. Indeed the VAI, which is a surrogate index of the adipose dysfunction, and the M-value, which is considered the gold standard of the insulin sensitivity evaluation, were found to be the independent variables significantly associated with the visfatin levels. Conversely, no association was found with IGF-1 levels.

We already demonstrated that acromegalic patients with high VAI show decreased insulin sensitivity and that the lipotoxicity secondary to the lipolytic action of GH could be clinically expressed by VAI [4]. These previous data are confirmed by the evidence in this study of higher NEFA levels in patients with uncontrolled disease, consistent with the data of Grottoli et al., who suggested the elevated levels of NEFAs caused by GH-stimulated lipolysis as one of the possible mechanisms leading to insulin resistance in acromegaly [36].

The levels of resistin, a potential marker of insulin resistance [37,38], were evaluated few times in acromegaly. In this study also resistin levels showed higher levels in uncontrolled than controlled patients, although not statistically significant, and this finding is partially consistent with previous studies. Indeed, other authors have already demonstrated no significant difference in resistin levels between acromegalic patients and control subjects and no correlation between resistin and GH/IGF I
Table 3

Correlation between leptin, visfatin, IGF-1 and metabolic parameters (univariate analysis).

\begin{tabular}{|c|c|c|c|c|c|c|}
\hline & \multicolumn{2}{|l|}{ Leptin } & \multicolumn{2}{|l|}{ Visfatin } & \multicolumn{2}{|l|}{ IGF-1 } \\
\hline & $r$ & $\mathrm{p}$ & $r$ & $\mathrm{p}$ & $r$ & $\mathrm{p}$ \\
\hline GH nadir & -0.430 & 0.009 & 0.255 & 0.133 & 0.620 & $<0.001$ \\
\hline IGF-1 & -0.594 & $<0.001$ & 0.683 & $<0.001$ & - & - \\
\hline Homa IR & -0.446 & 0.001 & 0.558 & $<0.001$ & 0.622 & $<0.001$ \\
\hline ISI Matsuda & 0.663 & $<0.001$ & -0.701 & $<0.001$ & -0.575 & $<0.001$ \\
\hline M-value (clamp) a & 0.281 & 0.217 & -0.447 & 0.042 & -0.616 & 0.003 \\
\hline BMI & -0.033 & 0.812 & 0.008 & 0.954 & 0.078 & 0.580 \\
\hline WC & 0.139 & 0.325 & -0.198 & 0.160 & -0.104 & 0.466 \\
\hline VAI & -0.500 & $<0.001$ & 0.724 & $<0.001$ & 0.595 & $<0.001$ \\
\hline
\end{tabular}

a Clamp was performed in a subgroup of 21 patients.

levels or insulin resistance indexes $[39,40]$. Fort these reasons, although the administration of $\mathrm{GH}$ in $\mathrm{GH}$-deficient rats has been shown to increase mRNA expression of resistin in white adipose tissue [41], in acromegalic patients $\mathrm{GH}$ does not seem to directly affect resistin levels.

Data on adiponectin levels in acromegalic patients are very controversial. Adiponectin is an insulin-sensitizing adipokine expressed in human adipose cells with anti-atherogenic and anti-inflammatory properties that plays a role in the pathophysiology of insulin resistance and metabolic syndrome [42-44]. Both a condition of hypoadiponectinemia and increased levels of adiponectin in acromegalic patients compared to control subjects have been demonstrated [35,45]. Silha et al. [39] showed increased adiponectin levels in acromegalic patients, without direct or inverse correlation with metabolic or hormonal parameters, probably because adiponectin are negatively correlated with body fat, which is reduced in acromegaly [46]. In the current study, we found no significant difference in adiponectin levels between uncontrolled and controlled patients, as well as in the different treatment groups, and these results are consistent with those of Ronchi et al. who did not demonstrate the validity of adiponectin as a marker of cardiovascular risk, because the lack of correlation with BMI, hormonal and metabolic parameters [47]. Therefore, acromegaly would differ from the other conditions of insulin resistance that are associated with hypoadiponectinemia $[48,49]$. Adipsin levels were found to be correlated with fat mass, metabolic syndrome and insulin secretion in non acromegalic patients [50-52]. Given the lack of data on adipsin in acromegaly and its potential metabolic role, we also aimed to analyze it in our cohort of patients but without finding any association with hormonal and metabolic parameters.

We believe that the strength of this study is given by the concomitant evaluation of selected adipokines and different insulin sensitivity indexes, especially the gold standard hyperinsulinemic euglycemic clamp, although it was performed only in a subgroup of patients. Indeed, the evaluation of insulin sensitivity through euglycemic clamp has been examined in a minority of studies and in smaller cohorts of patients [53-56]. Conversely, the limitations of this study are given by the small size of patients in each group of treatment and by the lack of a control group, because we compared the different acromegaly patients groups among themselves. In addition, the crosssectional design of the study could represent a limitation which could affect the reliability of results achieved in relatively small study groups.

In conclusion we found that in active acromegaly visfatin could be considered the most useful index of metabolic alterations, such as insulin resistance and adipose dysfunction, and disease control regardless of type of treatment and it seems to better correlate with the metabolic parameters than IGF-1.

Nevertheless, whether visfatin influences the metabolic parameters or otherwise remains to be demonstrated. We believe that the impact of adipokine status on the clinical and metabolic features in acromegaly remains to be further investigated and that additional prospective studies, that include larger study groups, are required to confirm the real utility of adipokine assessment in usual clinical settings. 
Table 4

Independent variables associated with leptin, visfatin and IGF-1 at multivariate analysis.

\begin{tabular}{|c|c|c|c|c|c|c|c|c|c|}
\hline \multirow[t]{2}{*}{ Independent variables } & \multicolumn{3}{|c|}{ Dependent variable: leptin } & \multicolumn{3}{|c|}{ Dependent variable: visfatin } & \multicolumn{3}{|c|}{ Dependent variable: IGF-1 } \\
\hline & $B$ & SE & $\mathrm{p}$ & $B$ & $S E$ & $\mathrm{p}$ & $B$ & SE & $\mathrm{p}$ \\
\hline GH nadir & -0.020 & 0.023 & 0.401 & - & - & - & 0.059 & 0.012 & 0.001 \\
\hline IGF-1 & -0.274 & 0.298 & 0.365 & 0.258 & 0.101 & 0.022 & - & - & - \\
\hline Homa IR & 0.040 & 0.132 & 0.766 & -0.088 & 0.084 & 0.312 & 0.332 & 0.146 & 0.049 \\
\hline ISI Matsuda & 0.398 & 0.161 & 0.019 & -0.209 & 0.070 & 0.010 & 0.096 & 0.129 & 0.475 \\
\hline M-value (clamp) ${ }^{\mathrm{a}}$ & - & - & - & 0.319 & 0.145 & 0.045 & -0.261 & 0.244 & 0.312 \\
\hline VAI & -0.025 & 0.200 & 0.903 & 0.243 & 0.077 & 0.007 & -0.120 & 0.146 & 0.429 \\
\hline
\end{tabular}

a Clamp was performed in a subgroup of 21 patients.

\section{References}

[1] H.M. Goodman, Multiple effects of growth hormone on lipolysis, Endocrinology 83 (1968) 300-308.

[2] A. Giustina, J.D. Veldhuis, Pathophysiology of the neuroregulation of growth hormone secretion in experimental animals and the human, Endocr. Rev. 19 (1998) 717-797.

[3] D.R. Clemmons, Roles of insulin-like growth factor-I and growth hormone in mediating insulin resistance in acromegaly, Pituitary 5 (2002) 181-183.

[4] A. Ciresi, M.C. Amato, G. Pizzolanti, C. Giordano Galluzzo, Visceral adiposity index is associated with insulin sensitivity and adipocytokine levels in newly diagnosed acromegalic patients, J. Clin. Endocrinol. Metab. 97 (2012) 2907-2915.

[5] P.U. Freda, W. Shen, S.B. Heymsfield, C.M. Reyes-Vidal, E.B. Geer, J.N. Bruce, D. Gallagher, Lower visceral and subcutaneous but higher intermuscular adipose tissue depots in patients with growth hormone and insulin-like growth factor I excess due to acromegaly, J. Clin. Endocrinol. Metab. 93 (2008) 2334-2343.

[6] N.C. Olarescu, A. Heck, K. Godang, T. Ueland, J. Bollerslev, The metabolic risk in newly diagnosed patients with acromegaly is related to fat distribution and circulating adipokines and improves after treatment, Neuroendocrinology (Jan 9. 2015) [Epub ahead of print].

[7] N.C. Olarescu, T. Ueland, K. Godang, R. Lindberg-Larsen, J.O. Jorgensen, J. Bollerslev, Inflammatory adipokines contribute to insulin resistance in active acromegaly and respond differently to different treatment modalities, Eur. J. Endocrinol. 170 (2013) 39-48.

[8] G. Frühbeck, J. Gómez-Ambrosi, F.J. Muruzábal, M.A. Burrell, The adipocyte: a model for integration of endocrine and metabolic signaling in energy metabolism regulation, Am. J. Physiol. Endocrinol. Metab. 280 (2001) E827-E847.

[9] J.N. Fain, A.K. Madan, M.L. Hiler, P. Cheema, S.W. Bahouth, Comparison of the release of adipokines by adipose tissue, adipose tissue matrix, and adipocytes from visceral and subcutaneous abdominal adipose tissues of obese humans, Endocrinology 145 (2004) 2273-2282.

[10] A.A. Bremer, I. Jialal, Adipose tissue dysfunction in nascent metabolic syndrome, J. Obes. 2013 (2013) 393192

[11] M.E. Trujillo, P.E. Scherer, Adipose tissue-derived factors: impact on health and disease, Endocr. Rev. 27 (2006) 762-778.

[12] A. Giustina, P. Chanson, M.D. Bronstein, A. Klibanski, S. Lamberts, F.F. Casanueva, P. Trainer, E. Ghigo, K. Ho, S. Melmed, Acromegaly Consensus Group, A consensus on criteria for cure of acromegaly, J. Clin. Endocrinol. Metab. 95 (2010) (2010) 3141-3148.

[13] D.R. Matthews, J.P. Hosker, A.S. Rudenski, B.A. Naylor, D.F. Treacher, R.C. Turner Homeostasis model assessment: insulin resistance and b-cell function from fasting plasma glucose and insulin in man, Diabetologia 28 (1985) 412-419.

[14] M. Matsuda, R.A. De Fronzo, Insulin sensitivity indices obtained from oral glucose tolerance testing: comparison with the euglycemic insulin clamp, Diabetes Care 24 (2001) 460-464.

[15] R.A. DeFronzo, J.D. Tobin, R. Andres, Glucose clamp technique: a method for quantifying insulin secretion and resistance, Am. J. Physiol. 237 (1979) E214-E223.

[16] M.C. Amato, C. Giordano, M. Galia, A. Criscimanna, S. Vitabile, M. Midiri, A. Galluzzo, For the AlkaMeSy Study Group, Visceral adiposity index (VAI): a reliable indicator of visceral fat function associated with cardiometabolic risk, Diabetes Care 33 (2010) 920-922.

[17] P.H. Sönksen, F.C. Greenwood, J.P. Ellis, C. Lowy, A. Rutherford, J.D. Nabarro, Changes of carbohydrate tolerance in acromegaly with progress of the disease and in response to treatment, J. Clin. Endocrinol. Metab. 27 (1967) 1418-1430.

[18] S. Melmed, Acromegaly, N. Engl. J. Med. 322 (1990) 966-977.

[19] A. Ciresi, M.C. Amato, R. Pivonello, E. Nazzari, L.F. Grasso, F. Minuto, D. Ferone, A Colao, C. Giordano, The metabolic profile in active acromegaly is gender-specific, J. Clin. Endocrinol. Metab. 98 (2013) E51-E59.

[20] C. Giordano, A. Ciresi, M.C. Amato, R. Pivonello, R.S. Auriemma, L.F. Grasso, A Galluzzo, A. Colao, Clinical and metabolic effects of first-line treatment with somatostatin analogues or surgery in acromegaly: a retrospective and comparative study, Pituitary 15 (2012) 539-551.

[21] S. Yamashita, T. Nakamura, I. Shimomura, M. Nishida, S. Yoshida, K. Kotani, K. Kameda-Takemuara, K. Tokunaga, Y. Matsuzawa, Insulin resistance and body fat distribution, Diabetes Care 19 (1996) 287-291.

[22] K.F. Petersen, E.A. Oral, S. Dufour, D. Befroy, C. Ariyan, C. Yu, G.W. Cline, A.M DePaoli, S.I. Taylor, P. Gorden, G.I. Shulman, Leptin reverses insulin resistance and hepatic steatosis in patients with severe lipodystrophy, J. Clin. Invest. 109 (2002) 1345-1350.
[23] C.M. Steppan, S.T. Bailey, S. Bhat, E.J. Brown, R.R. Banerjee, C.M. Wright, H.R. Patel, R.S. Ahima, M.A. Lazar, The hormone resistin links obesity to diabetes, Nature 409 (2001) 307-312

[24] O. Isozaki, T. Tsushima, M. Miyakawa, H. Demura, H. Seki, Interaction between leptin and growth hormone (GH)/IGF-I axis, Endocr. J. 46 (Suppl.) (1999) S17-S24.

[25] S.S. Damjanović, M.S. Petakov, S. Raicević, D. Micić, J. Marinković, C. Dieguez, F.F. Casanueva, V.J. Popović, Serum leptin levels in patients with acromegaly before and after correction of hypersomatotropism by trans-sphenoidal surgery, J. Clin. Endocrinol. Metab. 85 (2000) 147-154.

[26] K.C. Tan, A.W. Tso, K.S. Lam, Effect of Sandostatin LAR on serum leptin levels in patients with acromegaly, Clin. Endocrinol. (Oxf) 54 (2001) 31-35.

[27] R. Baldelli, C. Durante, E. D'Amico, F. Diacono, G. Tamburrano, F.F. Casanueva, Serum leptin levels in acromegalic patients before and during somatostatin analogs therapy, J. Endocrinol. Investig. 26 (2003) 1219-1224.

[28] C. Páramo, E. Fluiters, J. de la Fuente, A. Andrade, R.V. García-Mayor, Monitoring of treatment success in patients with acromegaly: the value of serum insulin-like growth factor binding protein-3 and serum leptin measurements in comparison to plasma insulin-like growth factor I determination, Metabolism 50 (2001) 1117-1121.

[29] J. Roemmler, B. Otto, A.M. Arafat, M. Bidlingmaier, J. Schopohl, Influence of pegvisomant on serum ghrelin and leptin levels in acromegalic patients, Eur. J. Endocrinol. 163 (2010) 727-734.

[30] C. Parkinson, A.J. Whatmore, A.P. Yates, W.M. Drake, G. Brabant, P.E. Clayton, P.J. Trainer, The effect of pegvisomant-induced serum IGF-I normalization on serum leptin levels in patients with acromegaly, Clin. Endocrinol. (Oxf) 59 (2003) 168-174.

[31] M. Bolanowski, A. Milewicz, B. Bidzińska, D. Jedrzejuk, J. Daroszewski, E. Mikulski, Serum leptin levels in acromegaly-a significant role for adipose tissue and fasting insulin/glucose ratio, Med. Sci. Monit. 8 (2002) CR685-CR689.

[32] V. Popovic, D. Micic, S. Danjanovic, S. Zoric, M. Djurovic, S. Obradovic, M. Petakov, C. Dieguez, F.F. Casanueva, Serum leptin and insulin concentrations in patients with insulinoma before and after surgery, Eur. J. Endocrinol. 138 (1998) 86-88.

[33] J.M. Fernández-Real, J.M. Moreno, B. Chico, A. López-Bermejo, W. Ricart, Circulating visfatin is associated with parameters of iron metabolism in subjects with altered glucose tolerance, Diabetes Care 30 (2007) 616-621.

[34] A. Fukuhara, M. Matsuda, M. Nishizawa, K. Segawa, M. Tanaka, K. Kishimoto, Y. Matsuki, M. Murakami, T. Ichisaka, H. Murakami, E. Watanabe, T. Takagi, M. Akiyoshi, T. Ohtsubo, S. Kihara, S. Yamashita, M. Makishima, T. Funahashi, S. Yamanaka, R. Hiramatsu, Y. Matsuzawa, I. Shimomura, Visfatin: a protein secreted by visceral fat that mimics the effects of insulin, Science 307 (2005) 426-430.

[35] N. Sucunza, M.J. Barahona, E. Resmini, J.M. Fernández-Real, W. Ricart, J. Farrerons, J. Rodríguez Espinosa, A.M. Marin, T. Puig, S.M. Webb, A link between bone mineral density and serum adiponectin and visfatin levels in acromegaly, J. Clin. Endocrinol. Metab. 94 (2009) 3889-3896.

[36] S. Grottoli, V. Gasco, A. Mainolfi, G. Beccuti, G. Corneli, G. Aimaretti, C. Dieguez, F. Casanueva, E. Ghigo, Growth hormone/insulin-like growth factor I axis, glucose metabolism, and lypolisis but not leptin show some degree of refractoriness to short-term fasting in acromegaly, J. Endocrinol. Investig. 31 (2008) 1103-1109.

[37] M. Degawa-Yamauchi, J.E. Bovenkerk, B.E. Juliar, W. Watson, K. Kerr, R. Jones, Q. Zhu, R.V. Considine, Serum resistin (FIZZ3) protein is increased in obese humans, J. Clin. Endocrinol. Metab. 88 (2003) 5452-5455.

[38] L.K. Heilbronn, J. Rood, L. Janderova, J.B. Albu, D.E. Kelley, E. Ravussin, S.R. Smith, Relationship between serum resistin concentrations and insulin resistance in nonobese, obese, and obese diabetic subjects, J. Clin. Endocrinol. Metab. 89 (2004) 1844-1848.

[39] J.V. Silha, M. Krsek, V. Hana, J. Marek, J. Jezkova, V. Weiss, L.J. Murphy, Perturbations in adiponectin, leptin and resistin levels in acromegaly: lack of correlation with insulin resistance, Clin. Endocrinol. (Oxf) 58 (2003) 736-742.

[40] S. Gurbulak, G.F. Yaylali, E. Yerlikaya, F. Akin, S. Topsakal, H. Tanrverdi, B. Akdag, A.R. Aslan, Resistin and leptin levels in acromegaly: lack of correlation with echocardiographic findings, J. Investig. Med. 61 (2013) 582-585.

[41] P.J. Delhanty, D. Mesotten, F. McDougall, R.C. Baxter, Growth hormone rapidly induces resistin gene expression in white adipose tissue of spontaneous dwarf (SDR) rats, Endocrinology 143 (2002) 2445-2448.

[42] T. Yamauchi, J. Kamon, H. Waki, Y. Terauchi, N. Kubota, K. Hara, Y. Mori, T. Ide, K. Murakami, N. Tsuboyama-Kasaoka, O. Ezaki, Y. Akanuma, O. Gavrilova, C. Vinson, M.L. Reitman, H. Kagechika, K. Shudo, M. Yoda, Y. Nakano, K. Tobe, R. Nagai, S. Kimura, M. Tomita, P. Froguel, T. Kadowaki, The fat-derived hormone adiponectin reverses insulin resistance associated with both lipoatrophy and obesity, Nat. Med. 7 (2001) 941-946. 
[43] J. Spranger, A. Kroke, M. Möhlig, M.M. Bergmann, M. Ristow, H. Boeing, A.F. Pfeiffer, Adiponectin and protection against type 2 diabetes mellitus, Lancet 361 (2003) 226-228.

[44] J.R. Kizer, D. Benkeser, A.M. Arnold, L. Djousse, S.J. Zieman, K.J. Mukamal, R.P. Tracy, C.S. Mantzoros, D.S. Siscovick, J.S. Gottdiener, J.H. Ix, Total and high-molecularweight adiponectin and risk of coronary heart disease and ischemic stroke in older adults, J. Clin. Endocrinol. Metab. 98 (2013) 255-263.

[45] K.S. Lam, A. Xu, K.C. Tan, L.C. Wong, S.C. Tiu, S. Tam, Serum adiponectin is reduced in acromegaly and normalized after correction of growth hormone excess, J. Clin. Endocrinol. Metab. 89 (2004) 5448-5453.

[46] M. Miyakawa, T. Tsushima, H. Murakami, O. Isozaki, H. Demura, T. Tanaka, Effect of growth hormone $(\mathrm{GH})$ on serum concentration of leptin: study in patients with acromegaly and GH deficiency, J. Clin. Endocrinol. Metab. 83 (1998) 3476-3479.

[47] C.L. Ronchi, S. Corbetta, V. Cappiello, P.S. Morpurgo, C. Giavoli, P. Beck-Peccoz, M. Arosio, A. Spada, Circulating adiponectin levels and cardiovascular risk factors in acromegalic patients, Eur. J. Endocrinol. 150 (2004) 663-669.

[48] Y. Arita, S. Kihara, N. Ouchi, M. Takahashi, K. Maeda, J. Miyagawa, K. Hotta, I. Shimomura, T. Nakamura, K. Miyaoka, H. Kuriyama, M. Nishida, S. Yamashita, K. Okubo, K. Matsubara, M. Muraguchi, Y. Ohmoto, T. Funahashi, Y. Matsuzawa, Paradoxical decrease of an adipose-specific protein, adiponectin, in obesity, Biochem. Biophys. Res. Commun. 257 (1999) 79-83.

[49] K. Hotta, T. Funahashi, Y. Arita, M. Takahashi, M. Matsuda, Y. Okamoto, H. Iwahashi, H. Kuriyama, N. Ouchi, K. Maeda, M. Nishida, S. Kihara, N. Sakai, T. Nakajima, K. Hasegawa, M. Muraguchi, Y. Ohmoto, T. Nakamura, S. Yamashita, T. Hanafusa, Y. Matsuzawa, Plasma concentrations of a novel, adipose-specific protein, adiponectin, in type 2 diabetic patients, Arterioscler. Thromb. Vasc. Biol. 20 (2000) 1595-1599.

[50] P. Chedraui, F.R. Pérez-López, G.S. Escobar, G. Palla, M. Montt-Guevara, E. Cecchi, A.R. Genazzani, T. Simoncini, Research Group for the Omega Women's Health Project,
Circulating leptin, resistin, adiponectin, visfatin, adipsin and ghrelin levels and insulin resistance in postmenopausal women with and without the metabolic syndrome, Maturitas 79 (2014) 86-90.

[51] J.C. Lo, S. Ljubicic, B. Leibiger, M. Kern, I.B. Leibiger, T. Moede, M.E. Kelly, D. Chatterjee Bhowmick, I. Murano, P. Cohen, A.S. Banks, M.J. Khandekar, A. Dietrich, J.S. Flier, S. Cinti, M. Blüher, N.N. Danial, P.O. Berggren, B.M. Spiegelman, Adipsin is an adipokine that improves $\beta$ cell function in diabetes, Cell 158 (2014) 41-53.

[52] A. Napolitano, B.B. Lowell, D. Damm, R.L. Leibel, E. Ravussin, D.C. Jimerson, M.D. Lesem, D.C. Van Dyke, P.A. Daly, P. Chatis, Concentrations of adipsin in blood and rates of adipsin secretion by adipose tissue in humans with normal, elevated and diminished adipose tissue mass, Int. J. Obes. Relat. Metab. Disord. 18 (1994) 213-218.

[53] C.E. Higham, S. Rowles, D. Russell-Jones, A.M. Umpleby, P.J. Trainer, Pegvisomant improves insulin sensitivity and reduces overnight free fatty acid concentrations in patients with acromegaly, J. Clin. Endocrinol. Metab. 94 (2009) 2459-2463.

[54] M.E. Ertorer O. Bakiner, I. Anaforoglu, E. Bozkirli, N.B. Tutuncu, N.G. Demirag, Lanreotide autogel and insulin sensitivity markers: report of 5 acromegalic patients and literature review, Neuro Endocrinol. Lett. 28 (2007) 727-733.

[55] R. Lindberg-Larsen, N. Møller, O. Schmitz, S. Nielsen, M. Andersen, H. Orskov, J.O. Jørgensen, The impact of pegvisomant treatment on substrate metabolism and insulin sensitivity in patients with acromegaly, J. Clin. Endocrinol. Metab. 92 (2007) 1724-1728.

[56] R. Baldelli, C. Battista, F. Leonetti, M.R. Ghiggi, M.C. Ribaudo, A. Paoloni, E. D'Amico, E. Ferretti, R. Baratta, A. Liuzzi, V. Trischitta, G. Tamburrano, Glucose homeostasis in acromegaly: effects of long-acting somatostatin analogues treatment, Clin. Endocrinol. (Oxf) 59 (2003) 492-499. 